\title{
Can we widen the scope of medical management in ectopic pregnancy?
}

\author{
Usha Kiran TS, Rajashree Dayanand Katke*, Priyadarshani mane
}

GGMC and JJH Group of Hospitals, Mumbai, India

Received: 10 February 2016

Revised: 15 February 2016

Accepted: 08 March 2016

\section{*Correspondence:}

Dr. Rajashree Dayanand Katke,

E-mail: drrajashreekatke@gmail.com

Copyright: (c) the author(s), publisher and licensee Medip Academy. This is an open-access article distributed under the terms of the Creative Commons Attribution Non-Commercial License, which permits unrestricted non-commercial use, distribution, and reproduction in any medium, provided the original work is properly cited.

\begin{abstract}
The objective of the study was to Safe Medical management of ectopic pregnancy in those where surgical management was indicated. Patients with one or more criteria not suitable for medical treatment but refusing surgical management were included. Exclusion criteria were those who were not haemodynamically stable. They were managed with close monitoring as inpatient to assess resolution of ectopic with Methotrexate. All five cases have been managed successfully by medical method. There is a possible role for medical management in patients who might not satisfy the criteria fully, however further research is needed. Ectopic pregnancy is life threatening disorder. With advances in diagnostic approaches such as ultrasound coupled with hormone markers diagnosis of ectopic has become easier in cases having first trimester bleeding per vaginum. Ectopic can be managed expectantly, medically and surgically. Medical management includes Inj. Methotrexate (MTX). In this case series we have studied five cases which are managed successfully with hundred percent successful results by medical management despite not satisfying criteria. It is a retrospective study. So from this study we can conclude that we can manage ectopic pregnancies medically based upon clinical judgment.
\end{abstract}

Keywords: Ectopic pregnancy, Methotrexate

\section{INTRODUCTION}

An ectopic pregnancy occurs when a fertilized ovum implants outside the normal uterine cavity. ${ }^{1-3}$ It is a common cause of morbidity and occasionally of mortality in women of reproductive age. In current practice, in developed countries, diagnosis relies on a combination of ultrasound scanning and serial serum beta-human chorionic gonadotropin ( $\beta$-hCG) measurements. ${ }^{4}$ This facility might not be always available in developing or under developed countries.

In the developed world, between $1 \%$ and $2 \%$ of all reported pregnancies are ectopic pregnancies (comparable to the incidence of spontaneous twin pregnancy. ${ }^{5}$ The incidence is thought to be higher in developing countries, but specific numbers are unknown. Although the incidence in the developed world has remained relatively static in recent years, between 1972 and 1992 there was an estimated six-fold rise in the incidence of ectopic pregnancy. ${ }^{6}$

There is marked increase in ectopic pregnancy rate with age from $6.6 / 1000$ pregnancies in women aged 15 to 24 to $21.5 / 1000$ pregnancies in women aged $35-44 .^{7}$ Indications for surgical management of ectopic pregnancy are haemodynamically unstable patient and failure of medical management after informed consent.

However, ectopic pregnancy is one of the few medical conditions that can also be managed expectantly or medically based on satisfying criteria. ${ }^{1,3,6,8-11} \mathrm{We}$ hereby present a case series of 5 patients who refused surgical management despite not fully satisfying the criteria for medical management. In these women, we successfully managed them medically after explaining the risks 
involved. All these patients were managed on inpatient basis with repeated methotrexate injections till there was a definite falling trend of B HCG with levels below 500 IU.

\section{CASE REPORT}

\section{Case 1}

27 year old women, Gravida3 Para1, Living1, Abortion1 with previous Lower Segment Caesarean section, presented with pain in the lower abdomen on left side \& spotting per vaginum. Ultrasound scan showed left adenexal cystic lesion with thick wall measuring $4 \times 2 \mathrm{~cm}$. Moderate Free fluid in Pouch of Douglas (POD) was noted. Serum beta HCG was 529.8IU/mL. Patient was haemodynamically stable. Total 3 doses of Inj. Methotrexate given on alternate day \& Inj. Leucovorin on alternate day. Serum beta HCG was repeated at 48 hours intervals till it showed a decreasing trend. It was negative in the third week.

\section{Case 2}

32 year woman, Gravida3 Abortion1 Ectopic1, presented with a history of laparotomy with right salphingectomy for ectopic pregnancy a year back. She was having spotting per vaginum \& pain in the lower abdomen. Clinical examination revealed right adnexal tenderness suggestive of ectopic pregnancy. Ultrasound scan showed a cystic lesion in right adnexa with irregular gestational sac and fetal echo content within. Mild free fluid was noted in the pouch of Douglas. Serum beta HCG was $11451 \mathrm{IU} / \mathrm{mL}$. Her vitals were stable. Five doses of Inj. Methotrexate and Inj. Leucovorin given every alternate day. Serum beta HCG levels became negative at 6 weeks.

\section{Case 3}

27 year woman, Gravida3 Para1 Living1 Abortion1 with previous Lower Segment Caesarean section presented with pain in left lower abdomen and spotting per vaginum of 3 days duration. Ultrasound scan showed $4.8 \times 4.5 \mathrm{~cm}$ heterogeneous complex cystic lesion in left adnexa with increased peripheral vascularity. Serum beta HCG was $256 \mathrm{IU} / \mathrm{mL}$. Clinical findings were suggestive of ectopic pregnancy. Patient was haemodynamically stable. She was given 3 doses of Inj. methotrexate \& Inj. Leucovorin on alternate day with monitoring of serum beta HCG level till it becomes negative on 3 week

\section{Case 4}

24 year woman, Gravida4 Para3 Living3 came with history of pain in the abdomen \& bleeding per vaginum since 15 days. On examination left forniceal tenderness was present \& vitals stable. USG showed $4.2 \times 4.6 \mathrm{~cm}$ left adnexal lesion adjacent to ovary with no vascularity. Beta HCG was $1472 \mathrm{IU} / \mathrm{mL}$. She was given 4 doses of Inj. methotrexate \& Inj. Leucovorin on alternate day with monitoring of beta HCG level till it becomes negative on week 5 .

\section{Case 5}

32 women, Gravida3 Para2 Living2 with 2 months of amenorrhea presented with pain abdomen and ultrasound scan showing right tubal ruptured ectopic gestation with moderate free fluid in POD. On examination - no cervical motion tenderness \&vitals stable. Serum beta HCG was $502 \mathrm{IU} / \mathrm{mL}$. One dose of Inj. methotrexate $\mathrm{f} / \mathrm{b}$ Inj. Leucovorin given. Serum beta HCG monitoring done till it becomes negative on week 1 .

Table 1: Relationship between USG criteria, dose of methotrexate and resolution time.

\begin{tabular}{|llllll|}
\hline Case & $\begin{array}{l}\text { Serum } \\
\text { beta } \\
\text { HCG }\end{array}$ & $\begin{array}{l}\text { Size of } \\
\text { ectopic } \\
\text { on } \\
\text { USG }\end{array}$ & $\begin{array}{l}\text { Amount } \\
\text { of free } \\
\text { fluid in } \\
\text { POD on } \\
\text { USG }\end{array}$ & $\begin{array}{l}\text { No. } \\
\text { of } \\
\text { doses } \\
\text { of } \\
\text { MTX }\end{array}$ & $\begin{array}{l}\text { Serum } \\
\text { beta } \\
\text { HCG } \\
\text { negative } \\
\text { on } \\
\text { (week) }\end{array}$ \\
\hline 1 & 529.8 & $4 \times 2 \mathrm{~cm}$ & Moderate & 3 & 3 \\
\hline 2 & 11451 & - & Mild & 5 & 6 \\
\hline 3 & 256 & $\begin{array}{l}4.8 \times 4.5 \\
\mathrm{~cm}\end{array}$ & - & 3 & 3 \\
\hline 4 & 1472 & $\begin{array}{l}4.2 \times 4.6 \\
\mathrm{~cm}\end{array}$ & - & 4 & 5 \\
\hline 5 & 502 & - & Moderate & 1 & 1 \\
\hline
\end{tabular}

\section{DISCUSSION}

In this series, we managed five of these cases medically without any complications. All five patients were haemodynamically stable with a Haemoglobin levels of more than $10 \mathrm{Gms} /$ at the time of admission. All patients had basal blood investigations which included complete blood count, liver function test and serum beta HCG at the time of admission and repeated 48 hourly until a definite declining trend of serum beta HCG was seen suggesting a responding/resolving ectopic pregnancy. Informed consent was taken and they were explained the risks of rupture and requiring emergency surgical management and blood transfusion.

In terms of criteria for medical management, as evident from table 1, all had one or two criteria which did not fit in. Three patients had ectopic gestations which were more either equal to or more than $4 \mathrm{~cm}$. Four of them had beta HCG levels within the criteria; however one patient had a very high level of 11451 with a fetal heart on ultrasound. One of them had moderate haemoperitonium and two had mild fluid in the POD.

There was a $100 \%$ success rate in our series with no complication whatsoever. They remained haemodynamically stable throughout and none of them required blood transfusion. Apart from one, all others required more than/equal to 3 injections of methotrexate. Maximum number of methotrexate required was 5 . 
Serum HCG levels became negative as early as one week to as late as 6 weeks. Dose of MTX required and the time taken for serum b HCG to become negative was directly proportional to the initial b HCG level.

Criteria for medical management are as follows:

1. Patients with an unruptured tubal ectopic pregnancy who are haemodynamically stable and have minimal symptoms and a low volume of free intraperitoneal fluid on ultrasound scan. ${ }^{9-11}$

2. If Beta hCG is below $5,000 \mathrm{mUI} / \mathrm{mL}$.

3. If the ectopic pregnancy is less than $4 \mathrm{~cm}$ in diameter or if the score is adequate when a scoring system prospectively evaluated can be used.

4. If there is no cardiac activity.

Intramuscular Methotrexate is the most widely used and successful medical therapy for ectopic pregnancy and is generally administered in a single-dose protocol. ${ }^{8}$

Methotrexate treatment is very successful for small stable ectopic pregnancies. However its side effects are as follows: Hepatotoxicity, acute stomatitis, low WBC count, pneumonitis, pulmonary fibrosis, teratogenicity, leucoencephalopathy, renal failure etc.

To the best of our knowledge this is the first case series presented where cases not within the criteria were managed medically.

The inference we draw from our study is that these cases can be managed medically but are not without risk of rupture and requiring emergency surgical management +/- blood transfusion. Hence they should be managed on an inpatient basis until there are definite signs of response to methotrexate, after which they can be monitored on as outpatient with CG monitoring in complaint patients.

A meta-analysis of non-randomised studies showed success rates of $93 \%$ (95\% CI $89-96 \%$ ) for multi-dose protocols and $88 \%$ (95\% CI 86-90\%) for single dose therapy. Failure of single-dose medical management is associated with initial serum $\beta$-hCG concentrations $>5000 \mathrm{IU} / 1$, a moderate or large amount of free fluid on ultrasound, the presence of fetal cardiac activity and a pre-treatment increase in serum $\beta$-hCG of $>50 \%$ over a 48 -hour period. This was similar to our study. In patients requiring multiple doses of methotrexate, appropriate monitoring of LFT and CBC and folic acid to prevent side effects is essential.

\section{CONCLUSION}

In Conclusion, we can say that there is a role to explore medical management in patients who might not satisfy the criteria fully as it not only decreases the surgical/anaesthetic risks but might come in handy in patients who or either not willing or unfit for surgery.

However a larger study is required before revised protocol/criteria for medical management can be formulated.

\section{Funding: Not required \\ Conflict of interest: None declared \\ Ethical approval: Not required}

\section{REFERENCES}

1. Walker JJ. Ectopic pregnancy. Clin Obstet Gynecol. 2007;50:89-99.

2. Della-Giustina D, Denny M. Ectopic pregnancy. Emerg Med Clin North Am. 2003;21:565-84.

3. Varma R, Gupta J. Tubal ectopic pregnancy. Clin Evid. 2009;2009:1406.

4. Horne AW, Duncan WC, Critchley HO. The need for serum biomarker development for diagnosing and excluding tubal ectopic pregnancy. Acta Obstet Gynecol Scand. 2010;89:299-301.

5. Goldner TE, Lawson HW, Xia Z, et al. Surveillance for ectopic pregnancy - United States, 1970-1989. MMWR CDC Surveill Summ. 1993;42:73-85.

6. Chang J, Elam-Evans LD, Berg CJ, et al. Pregnancyrelated mortality surveillance - United States, 19911999. MMWR Surveill Summ. 2003;52:1-8.

7. Copyright Molson medical informatics project at McGill University, 2000.

8. Condous G, Timmerman D, Goldstein S, et al. Pregnancies of unknown location: consensus statement. Ultrasound Obstet Gynecol. 2006;28:1212 .

9. Lipscomb GH, McCord ML, Stovall TG. Predictors of success of methotrexate treatment in women with tubal ectopic pregnancies. $\mathrm{N}$ Engl $\mathrm{J}$ Med. 1999;341:1974-8.

10. Lipscomb GH, Bran D, McCord ML. Analysis of three hundred fifteen ectopic pregnancies treated with single-dose methotrexate. Am J Obstet Gynecol. 1998;178:1354-8.

11. Sowter MC, Farquhar CM, Petrie KJ, et al. A randomised trial comparing single dose systemic methotrexate and laparoscopic surgery for the treatment of unruptured tubal pregnancy. BJOG. 2001;108:192-203.

Cite this article as: Usha Kiran TS, Katke RD, Mane P. Can we widen the scope of medical management in ectopic pregnancy? Int J Reprod Contracept Obstet Gynecol 2016;5:1257-9. 